\title{
The dilemma of widal test - which brand to use? a study of four different widal brands: a cross sectional comparative study
}

\author{
Wafaa MK Bakr ${ }^{*}$, , Laila A El Attar ${ }^{\dagger}$, Medhat S Ashour ${ }^{\dagger}$, Ayman M El Toukhy ${ }^{\dagger}$
}

\begin{abstract}
Background: Serodiagnosis of typhoid fever by Widal test based on demonstrating the presence of agglutinins (antibodies) in the serum of an infected patient, against the $\mathrm{H}$ (flagellar) and $\mathrm{O}$ (somatic) antigens of Salmonella enterica serotype Typhi has been associated with many debates. This is why the aim of this study was to: (i) Compare the diagnostic accuracy of four different commercial kits used to perform Widal test (Remel, BioSystems, Dialab and Biotec). (ii) Compare the sensitivity and specificity of both anti-O and anti-H antibodies. (iii) Compare the validity of single versus paired serum samples with a rising titer for the diagnosis of typhoid fever.

Methods: Duplicate serum samples were obtained from150 patients clinically diagnosed as typhoid fever patients. Moreover, single serum samples were obtained from 25 patients with febrile diseases other than typhoid fever. All samples were tested using the four different Widal brands and Salmonella Typhi IgM anti-LPS ELISA

Results: -The results of Widal tests differed markedly using the four Widal brands in terms of sensitivity and specificity at three cut-off values of 1/80,1/160 and 1/320. Remel brand gave the highest sensitivities and the lowest specificities and Dialab brand gave the highest specificities and the lowest sensitivities for both anti-O and anti-H antibodies at the three cut-off values.

-Four fold rise in the antibodies titer was not demonstrable among clinically diagnosed typhoid fever patients - $\mathrm{H}$ agglutinins were less sensitive and less specific than $\mathrm{O}$ agglutinins
\end{abstract}

Conclusions: -Widal test results showed marked discrepancies using different Widal brands. None of the serum samples of the typhoid fever patients showed four fold rise in the antibody titers. Raised $O$ agglutinins were of slightly greater diagnostic value than raised $\mathrm{H}$ agglutinins.

Significance and impact of study: Widal test done sequentially using two brands could be of value in typhoid fever diagnosis. Single serum sample could be used for typhoid fever diagnosis relying on anti $O$ titer.

\section{Introduction}

Typhoid fever, one of the enteric diseases, is endemic in Egypt [1]. Population-based studies indicated that typhoid fever incidence is 10-100/100,000 per year, with an annual peak in August [1]. An incidence of 13/100,000 persons per year was estimated in a household survey conducted in Belbis district in 2003 [2], while an incidence of $61 / 100,000$ persons per year was estimated in Fayoum in 2002 [3].

\footnotetext{
* Correspondence: wafaabakr@hotmail.com

† Contributed equally

Microbiology Department, High Institute of Public Health, Alexandria University, High Institute of Public Health, 165 Al Horreya avenue, Alexandria, Egypt
}

\section{Biomed Central}

(C) 2011 Bakr et al; licensee BioMed Central Ltd. This is an Open Access article distributed under the terms of the Creative Commons Attribution License (http://creativecommons.org/licenses/by/2.0), which permits unrestricted use, distribution, and reproduction in any medium, provided the original work is properly cited.
The diagnosis of typhoid fever on clinical grounds is difficult, as the presenting symptoms are diverse and similar to those observed with other febrile illnesses [4].

Serodiagnosis of typhoid fever has been attempted since the late nineteenth century by Widal and Secard [5]. The test was based on demonstrating the presence of agglutinins (antibodies) in the serum of an infected patient, against the $\mathrm{H}$ (flagellar) and $\mathrm{O}$ (somatic) antigens of Salmonella enterica serotype Typhi ( $S$. Typhi). While the definitive diagnosis of typhoid fever depends on the isolation of $S$. Typhi from blood, stools, urine or other body fluids [6,7], the role of the Widal test has been to increase the index of suspicion for the presence of 
typhoid fever by demonstrating a positive agglutination during the acute and convalescent period of infection with evidence of four fold rise in antibody titer [8-10].

Over 100 years since its introduction as a serologic means of detecting the presence of typhoid fever, the Widal test continues to be plagued with controversies involving the quality of the antigens used and interpretation of the result, particularly in endemic areas [11].

Hoffman et al. stated that the results of single Widal test, tube dilution or slide agglutination test are virtually un-interpretable unless the sensitivity and specificity of the test for the specific laboratory and patient population are known [12]. Olopenia and King stated that the value of Widal test depends upon the standardization and maintenance of the antigens to produce consistent results. They also mentioned that even since 1936 when Welch stated that no Widal test, regardless of the composition and standardization of the antigens used is infallible, and thus it is unlikely that any will be developed that will lower the validity of the isolation of the etiologic agent. Unfortunately, more than 70 years after Welch published his paper, the problems of insensitivity and non-specificity of Widal antigens continue [11].

Many authors stated that the recommended definitive interpretation of the Widal test is four fold rise in agglutinins in sera taken 7 to 10 days apart $[8,13]$. Four folds increase is not always demonstrable even in blood culture-confirmed cases $[11,14,15]$.

Regarding $\mathrm{O}$-agglutinin and $\mathrm{H}$-agglutinin titer, Huckstep have claimed that the level of $\mathrm{H}$ agglutinins is unhelpful in the diagnosis of typhoid, maintaining that the $\mathrm{H}$-agglutinin titer remains elevated for a longer period than the O-agglutinin titer after an episode of typhoid fever and also may rise as a nonspecific response to other infections [16]. However Brodie, Coovadia, Pang and Sommerville have proposed that the $\mathrm{H}$-agglutinin titer is as useful as or more useful than the O-agglutinin titer [9,17-19]. While Parry stated that $\mathrm{H}$ agglutinins were less sensitive but more specific than $\mathrm{O}$ agglutinins and yielded better positive predictive values [20].

Hence the specific purpose of this study was to find a clue to some of these debates concerning Widal test.

\section{Subjects and methods}

After obtaining the approval of the ethical committee of the Egyptian Ministry of Health. Patients and controls at the inpatient ward of Desouk fever hospital, kafr ElShekh governorate, Egypt, have been invited to participate in this research. Those who accepted were recruited after obtaining their (or their parents) consents.

\section{Typhoid fever patients group}

This group included 150 patients, 85 males and 65 females, with age ranging from 4 years to 65 years (mean age of $27.6 \pm 23.33$ years). They were clinically suspected of typhoid fever (suffering from continuous fever greater than $38^{\circ} \mathrm{C}$ in addition to headache, constipation or diarrhea).

\section{Hospital control group}

This group included 25 patients (15 males and 10 females with mean age of $31.68 \pm 19$ years) with febrile diseases other than typhoid fever that have been diagnosed after both clinical examination and laboratory investigation. They included 12 patients with urinary tract infection, 5 patients with chest infection, 4 patients with brucellosis and 4 patients with measles.

\section{Samples collection}

Paired blood samples were collected from typhoid fever patients group (300 samples). The first blood sample was obtained from 2 to 10 days from appearance of symptoms while the second sample was obtained one week interval from the first one. A single blood sample was collected from patients in the hospital control group (25 samples). Blood samples were centrifuged and sera were separated and stored at $-20^{\circ} \mathrm{C}$.

\section{Tests carried out}

\section{- Widal test}

Widal test was performed on both first and second serum samples using the following 4 commercially available brands:

A) Remel: Remel stained Salmonella O and H suspensions, Remel Europe ltd, UK

B) BioSystems: Febrile serodiagnostic agglutination slides and tubes, Biosystems S A, Barcelona, Spain

C) Dialab: Bacterial agglutination test, Dialab, Austria

D) Biotec: Stained bacterial antigen suspensions, Biotec, UK

\section{Reagents in kits}

Vials of $5 \mathrm{ml}$ which contain standardized stained smooth Salmonella suspensions of killed bacteria which have been stained to facilitate readings of agglutination tests. These bacterial antigens were: Salmonella Typhi O, Salmonella Typhi H, Salmonella Paratyphi A-H and Salmonella Paratyphi B-H.

\section{Test procedure}

All samples were first screened by slide agglutination technique, when proven to be positive, they were further tested by tube agglutination technique.

\section{Slide agglutination technique}

- Fifty microliters of undiluted serum were placed in a $3 \mathrm{~cm}$ diameter circle on a white tile 
- One drop (50 microliters) of the appropriate wellshaken Widal suspension (both anti $\mathrm{O}$ and anti $\mathrm{H}$ ) was added using the dropper provided. In performing the procedure using Remel brand, 20 microliters (instead of 50 microliters) of serum were used

- The contents were mixed by stirring for a few seconds and spread to fill the whole area of a circle on the tile. The tile was rotated slowly and agglutination was observed for one minute.

- Clumping within one minute was considered positive. The reaction obtained was roughly equivalent to this which would be obtained in a tube agglutination test with serum dilution of $1 / 80$.

\section{Tube agglutination technique}

- The patient's sera were serially diluted ( 2 fold) in normal saline, starting by $1 / 80$ to obtain dilutions of $1 / 80$, $1 / 160,1 / 320,1 / 640$, and $1 / 1280$. One $\mathrm{ml}$ of each dilution was dispensed in each of 8 tubes making two rows each of 4 tubes. For the first row of tubes a drop of anti $\mathrm{O}$ antibodies (of each of the four used Widal brands) was added, while to the second row of tubes a drop of anti $\mathrm{H}$ antibodies (of each of the four used Widal brands) was added. A tube containing $1 \mathrm{ml}$ saline was included as a negative control. All tubes were mixed, $\mathrm{O}$ suspensions were incubated at $50^{\circ} \mathrm{C}$ for 4 hours and $\mathrm{H}$ suspensions were incubated at $50^{\circ} \mathrm{C}$ for 2 hours. In a positive $\mathrm{O}$ reaction, there was a granular agglutination; while $\mathrm{H}$ agglutination has a characteristic floccular appearance. In a negative reaction and in the saline the appearance of the suspension should be unchanged, and show a typical swirl when the tube is flicked. The tubes were not shaken. The titer in each case is the highest tube dilution of the serum showing agglutination. Figure 1, 2

\section{ELISA test (Salmonella Typhi IgM anti-LPS ELISA BIO- QUANT INC, USA)}

-In the present study detection of $S$. Typhi by culture methods was not done, instead ELISA test was performed as a comparative test to Widal on the first serum sample of 91 randomly chosen patients of the 150 clinically diagnosed typhoid fever patients.

\section{Assay procedure}

The test was performed according to the manufacturer instructions.

\section{Statistical analysis}

The data were collected and statistical analysis was done. The statistical tests used namely sensitivity, specificity and accuracy. These were calculated by using the following formulas: Sensitivity is $a /(a+c)$, specificity is $d /(d+b)$, accuracy $a+d /(a+b+c+d)$, where $a$ is positive ELISA and Widal test, $b$ is Negative ELISA, but positive Widal test, $c$ is Positive ELISA, but negative Widal test, and $d$ is Negative ELISA, and negative Widal test [21].

\section{Results}

Of the 150 clinically diagnosed typhoid fever patients included in the present study, 85 (56.7\%) were males and $65(43.3 \%)$ were females, with a mean age of $27.6 \pm 23.33$ years. The corresponding figures of the 25 hospital controls were 15 (60\%) males and 10 (40\%) females with mean age of $31.68 \pm 19$ years. The main presenting symptom was fever among 149 (99.3\%) cases and all (100\%) the 25 hospital controls. The second main presenting symptom was headache which was observed in 113 (75.3\%) cases and 12 (48\%) hospital controls. Constipation was more common among cases than diarrhea, it was observed in $74(49.3 \%)$ cases, while diarrhea was observed in 62 (41.3\%) cases. Regarding antibiotics intake, 140 (93.3\%) of the 150 clinically diagnosed typhoid fever cases and 24 (96\%) of the hospital controls received antibiotics before hospitalization.

Regarding the antibody titer assay of the first serum samples of the150 clinically diagnosed typhoid fever cases by the four used Widal brands, marked discrepancies were obtained. (Table 1)

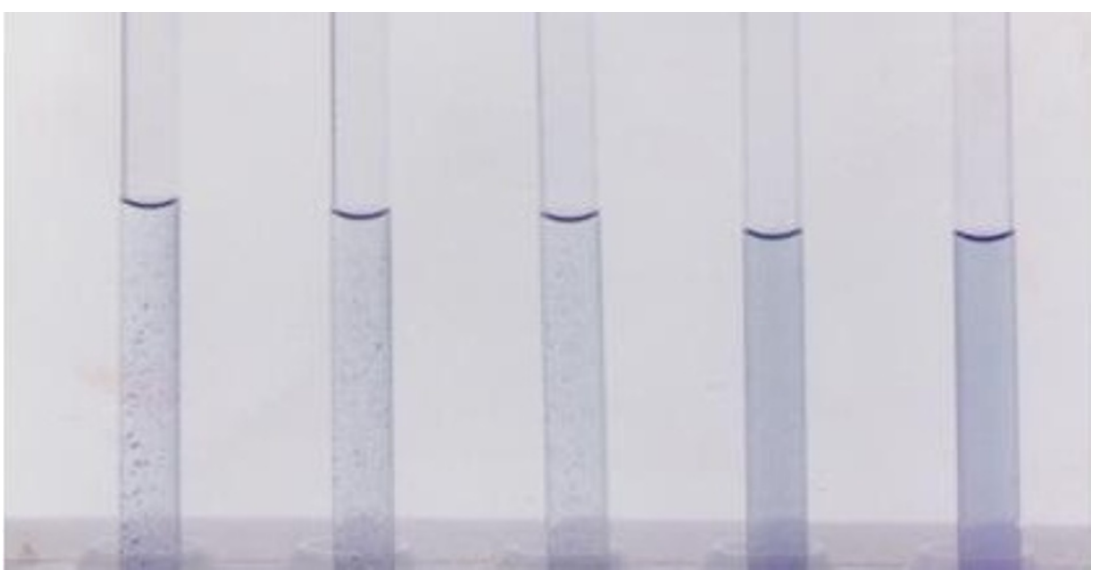

Figure 1 Positive Widal test for anti-O antibodies. 


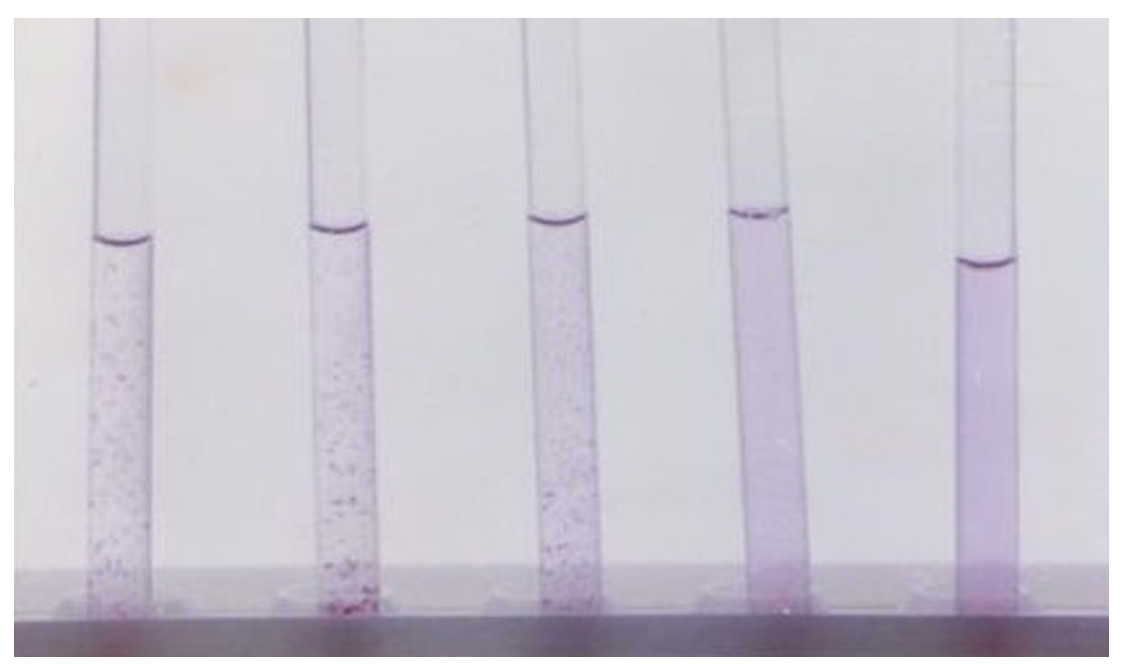

Figure 2 Positive Widal test for anti-H antibodies

Of the 25 hospital controls diagnosed with febrile illnesses other than typhoid, only one serum sample gave positive Widal test result at a titer of $1 / 80$ when using each of Remel, Biosystems and Biotech brands, while none of the samples reacted with Dialab brand at any titer. It should be mentioned that in Egypt the Ministry of Health and Population (MHP) consider a diagnostic titer for typhoid fever to be of $1 / 160$ for both anti $O$ and anti $\mathrm{H}$ antibodies.

Considering the difference in titers between the first and second serum samples (one week interval) of the150 clinically diagnosed typhoid fever cases none of these samples showed a three or four fold increase upon second testing for either anti-O and anti- $\mathrm{H}$ antibodies by any of the used Widal brands.

For comparison of the sensitivity, specificity and accuracy of the 4 used Widal brands, IgM anti-LPS ELISA test was performed as a reference test on the first serum sample of 91 randomly chosen patients of the 150 clinically diagnosed typhoid fever patients.
Table 2, 3, 4 shows the distribution of the results of 91 serum samples using the 4 Widal brands at a $1 / 80$, $1 / 160$ and1/320 cut-off values for anti-O antibodies in relation to their corresponding IgM anti-LPS ELISA results. Out of 91 serum samples tested by the ELISA IgM anti-LPS antibodies, 67 samples (73.62\%) showed positive results. All these samples gave titers of $\geq 1 / 80$ in the Widal test by using each of the Remel and Biosystems brands, while only 65 (97.01\%) and 59 (88.05\%) samples showed these titers when using the Biotech and Dialab brands respectively.

Table 5 shows the sensitivity, specificity and accuracy of the 4 Widal brands for anti-O antibodies using cutoff values of $1 / 80,1 / 160$ and $1 / 320$ respectively using IgM anti-LPS ELISA as a reference test.

Regarding the sensitivity of the 4 brands, it is clear that, each of Remel and biosystems brands showed the highest sensitivity compared to the other 2 used brands at the 3 cut-off values. However the sensitivity of these brands decreased by increasing the cut-off value it

Table 1 Antibody titers of the 150 clinically diagnosed typhoid fever cases in the first serum samples using 4 different Widal brands

\begin{tabular}{|c|c|c|c|c|c|c|c|c|c|c|c|c|}
\hline \multirow{3}{*}{$\begin{array}{l}\text { Widal } \\
\text { brand }\end{array}$} & \multirow{2}{*}{\multicolumn{2}{|c|}{$\begin{array}{l}\text { Total No. of } \\
\text { positive samples (\%) }\end{array}$}} & \multicolumn{10}{|c|}{ No. of samples with given reciprocal titer } \\
\hline & & & \multicolumn{2}{|l|}{80} & \multicolumn{2}{|c|}{160} & \multicolumn{2}{|c|}{320} & \multicolumn{2}{|l|}{640} & \multicolumn{2}{|c|}{1280} \\
\hline & 0 & $\mathrm{H}$ & 0 & $\mathbf{H}$ & 0 & $\mathrm{H}$ & 0 & $\mathrm{H}$ & 0 & $\mathrm{H}$ & 0 & $\mathrm{H}$ \\
\hline Remel & $\begin{array}{l}131 \\
(87.34)\end{array}$ & $\begin{array}{l}141 \\
(94.00)\end{array}$ & 23 & 14 & 42 & 60 & 45 & 32 & 19 & 25 & 2 & 10 \\
\hline Biosystems & $\begin{array}{l}129 \\
(86.00)\end{array}$ & $\begin{array}{l}136 \\
(90.66)\end{array}$ & 32 & 15 & 47 & 60 & 35 & 35 & 13 & 18 & 2 & 8 \\
\hline Biotech & $\begin{array}{l}125 \\
(83.34)\end{array}$ & $\begin{array}{l}129 \\
(86.00)\end{array}$ & 28 & 25 & 59 & 55 & 30 & 25 & 8 & 20 & 0 & 4 \\
\hline Dialab & $\begin{array}{l}103 \\
(68.67)\end{array}$ & $\begin{array}{l}106 \\
(70.66)\end{array}$ & 46 & 42 & 49 & 41 & 8 & 22 & 0 & 1 & 0 & 0 \\
\hline
\end{tabular}


Table 2 Distribution of the results of 91 serum samples using the $\mathbf{4}$ Widal brands for anti-O antibodies in relation to their corresponding IgM anti-LPS ELISA results using a cut-off $1 / 80$

\begin{tabular}{|c|c|c|c|c|c|c|}
\hline \multirow{3}{*}{$\begin{array}{l}\text { Widal } \\
\text { brand }\end{array}$} & \multirow{3}{*}{$\begin{array}{l}\text { anti }-0 \\
\text { titer } \geq 1 / 80\end{array}$} & \multicolumn{4}{|c|}{ ELISA (91) } & \multirow[t]{3}{*}{ Total } \\
\hline & & \multicolumn{2}{|c|}{ Positive (67) } & \multicolumn{2}{|c|}{ Negative (24) } & \\
\hline & & Number & $\%$ & Number & $\%$ & \\
\hline \multirow[t]{2}{*}{ Remel } & Negative & 0 & 0.00 & 13 & 54.16 & 13 \\
\hline & Positive & 67 & 100.00 & 11 & 45.83 & 78 \\
\hline \multirow[t]{2}{*}{ Biosystems } & Negative & 0 & 0.00 & 14 & 58.33 & 14 \\
\hline & Positive & 67 & 100.00 & 10 & 41.66 & 77 \\
\hline \multirow[t]{2}{*}{ Biotech } & Negative & 2 & 2.98 & 14 & 58.33 & 16 \\
\hline & Positive & 65 & 97.01 & 10 & 41.66 & 75 \\
\hline \multirow[t]{2}{*}{ Dialab } & Negative & 8 & 11.94 & 22 & 91.66 & 30 \\
\hline & Positive & 59 & 88.05 & 2 & 8.33 & 61 \\
\hline
\end{tabular}

decreased from $100 \%$ at cut-off titer of $1 / 80$, to $89.5 \%$ at cut-off titer of $1 / 160$ and to $59.7 \%$ at cut-off titer of $1 / 320$ for Remel brand. The corresponding figures for Biosystems brand were $100 \%, 83.58 \%$ and $46.26 \%$ respectively.

Regarding the specificity, Dialab brand was the most specific brand (91.66\%) at the cut-off value of $1 / 80$, however, at a cut-off value of 1/160 both Dialab and Biosystems brand were the most specific brands $(95.83 \%$ for both brands). By increasing the cut-off value to $1 / 320$, the four brands showed the same specificity (100\%).

The accuracy of the 4 used brands was almost the same when using a cut-off of $1 / 80$.

However Remel brand was the most accurate brand using the cut-off values of $1 / 160$ and $1 / 320$ (87.91\% and $70.23 \%$ respectively)

Table 3 Distribution of the results of 91 serum samples using the 4 Widal brands for anti-O antibodies in relation to their corresponding IgM anti-LPS ELISA results using a cut-off $1 / 160$

\begin{tabular}{|c|c|c|c|c|c|c|}
\hline \multirow{3}{*}{$\begin{array}{l}\text { Widal } \\
\text { brand }\end{array}$} & \multirow{3}{*}{$\begin{array}{c}\text { anti-O titer } \geq \\
1 / 160\end{array}$} & \multicolumn{4}{|c|}{ ELISA (91) } & \multirow[t]{3}{*}{ Total } \\
\hline & & \multicolumn{2}{|c|}{ Positive (67) } & \multicolumn{2}{|c|}{ Negative (24) } & \\
\hline & & Number & $\%$ & Number & $\%$ & \\
\hline \multirow[t]{2}{*}{ Remel (91) } & Negative & 7 & 10.44 & 20 & 83.33 & 27 \\
\hline & Positive & 60 & 89.55 & 4 & 16.66 & 64 \\
\hline \multirow{2}{*}{$\begin{array}{l}\text { Biosystems } \\
\text { (91) }\end{array}$} & Negative & 11 & 16.41 & 23 & 95.83 & 34 \\
\hline & Positive & 56 & 83.58 & 1 & 4.16 & 57 \\
\hline \multirow{2}{*}{$\begin{array}{l}\text { Biotech } \\
\text { (91) }\end{array}$} & Negative & 13 & 19.4 & 20 & 83.33 & 33 \\
\hline & Positive & 54 & 80.59 & 4 & 16.66 & 58 \\
\hline \multirow[t]{2}{*}{ Dialab (91) } & Negative & 35 & 52.23 & 23 & 95.83 & 58 \\
\hline & Positive & 32 & 47.76 & 1 & 4.16 & 33 \\
\hline
\end{tabular}

Table 4 Distribution of the results of 91 serum samples using the $\mathbf{4}$ Widal brands for anti-O antibodies in relation to their corresponding IgM anti-LPS ELISA results using a cut-off $1 / 320$

\begin{tabular}{|c|c|c|c|c|c|c|}
\hline \multirow{3}{*}{$\begin{array}{l}\text { Widal } \\
\text { brand }\end{array}$} & \multirow{3}{*}{$\begin{array}{c}\text { anti-O titer } \geq \\
1 / 320\end{array}$} & \multicolumn{4}{|c|}{ ELISA (91) } & \multirow[t]{3}{*}{ Total } \\
\hline & & \multicolumn{2}{|c|}{ Positive (67) } & \multicolumn{2}{|c|}{ Negative (24) } & \\
\hline & & Number & $\%$ & Number & $\%$ & \\
\hline \multirow[t]{2}{*}{ Remel (91) } & Negative & 27 & 40.29 & 24 & 100.00 & 51 \\
\hline & Positive & 40 & 59.7 & 0 & 0.00 & 40 \\
\hline \multirow{2}{*}{$\begin{array}{c}\text { Biosystems } \\
\text { (91) }\end{array}$} & Negative & 36 & 53.73 & 24 & 100.00 & 60 \\
\hline & Positive & 31 & 46.26 & 0 & 0.00 & 31 \\
\hline \multirow{2}{*}{$\begin{array}{l}\text { Biotech } \\
(91)\end{array}$} & Negative & 43 & 64.17 & 24 & 100.00 & 67 \\
\hline & Positive & 24 & 35.82 & 0 & 0.00 & 24 \\
\hline \multirow[t]{2}{*}{ Dialab (91) } & Negative & 65 & 97.01 & 24 & 100.00 & 89 \\
\hline & Positive & 2 & 2.98 & 0 & 0.00 & 2 \\
\hline
\end{tabular}

Tables $6,7,8$ show the distribution of the results of 91 serum sample using the 4 Widal brands at a $1 / 80$, $1 / 160$ and $1 / 320$ cut-off values for anti-H antibodies in relation to their corresponding IgM anti-LPS ELISA results. It was clear from this table, that none of the used Widal brands could diagnose the 67 serum samples diagnosed by ELISA for IgM antibodies. At 1/80, 1/160 and $1 / 320$ cut-off values the highest sensitivity $(94.02 \%$, $83.58 \%$ and $56.71 \%$ ) was obtained by Remel brand and

Table 5 Sensitivity, specificity and accuracy of the 4 Widal brand for anti-O antibodies of 91 random serum samples of the 150 clinically diagnosed typhoid fever cases using IgM anti-LPS ELISA as a reference test at three cut-off values

\begin{tabular}{llll}
\hline Using a cut-off $\mathbf{1 / 8 0}$ & & & \\
\hline Brand & sensitivity & specificity & accuracy \\
\hline Remel & $100.00 \%$ & $54.16 \%$ & $87.91 \%$ \\
\hline Biosystems & $100.00 \%$ & $58.33 \%$ & $89.01 \%$ \\
\hline Biotech & $97.00 \%$ & $58.33 \%$ & $86.81 \%$ \\
\hline Dialab & $88.10 \%$ & $91.66 \%$ & $89.01 \%$ \\
\hline Using a cut-off $\mathbf{1 / 1 6 0}$ & & & \\
\hline Remel & $89.50 \%$ & $83.33 \%$ & $87.91 \%$ \\
\hline Biosystems & $83.58 \%$ & $95.83 \%$ & $86.81 \%$ \\
\hline Biotech & $80.59 \%$ & $83.33 \%$ & $81.31 \%$ \\
\hline Dialab & $47.76 \%$ & $95.83 \%$ & $60.40 \%$ \\
\hline Using a cut-off1/320 & & & \\
\hline Remel & $59.70 \%$ & $100.00 \%$ & $70.32 \%$ \\
\hline Biosystems & $46.26 \%$ & $100.00 \%$ & $60.43 \%$ \\
\hline Biotech & $35.82 \%$ & $100.00 \%$ & $52.74 \%$ \\
\hline Dialab & $2.89 \%$ & $100.00 \%$ & $28.57 \%$ \\
\hline
\end{tabular}


Table 6 Distribution of the results of 91 serum samples using the $\mathbf{4}$ Widal brands for anti-H antibodies in relation to their corresponding IgM anti-LPS ELISA results using a cut-off $1 / 80$

\begin{tabular}{|c|c|c|c|c|c|c|}
\hline \multirow{3}{*}{$\begin{array}{l}\text { Widal } \\
\text { brand }\end{array}$} & \multirow{3}{*}{$\begin{array}{c}\text { anti-H titer } \geq \\
1 / 80\end{array}$} & \multicolumn{4}{|c|}{ ELISA (91) } & \multirow[t]{3}{*}{ Total } \\
\hline & & \multicolumn{2}{|c|}{ Positive (67) } & \multicolumn{2}{|c|}{ Negative (24) } & \\
\hline & & Number & $\%$ & Number & $\%$ & \\
\hline \multirow[t]{2}{*}{ Remel } & Negative & 4 & 5.97 & 2 & 8.33 & 6 \\
\hline & Positive & 63 & 94.02 & 22 & 91.66 & 85 \\
\hline \multirow[t]{2}{*}{ Biosystems } & Negative & 6 & 8.95 & 4 & 16.66 & 10 \\
\hline & Positive & 61 & 91.04 & 20 & 83.33 & 81 \\
\hline \multirow[t]{2}{*}{ Biotech } & Negative & 9 & 13.43 & 5 & 20.83 & 14 \\
\hline & Positive & 58 & 86.56 & 19 & 79.16 & 77 \\
\hline \multirow[t]{2}{*}{ Dialab } & Negative & 18 & 26.86 & 11 & 45.83 & 29 \\
\hline & Positive & 49 & 73.13 & 13 & 54.16 & 62 \\
\hline
\end{tabular}

the lowest sensitivity $(73.13 \%, 55.22 \%$ and $19.4 \%)$ was obtained by Dialab brand.

Table 9 shows sensitivity, specificity and accuracy of the 4 Widal brands for anti- $\mathrm{H}$ antibodies using cut-off values of $1 / 80,1 / 160$ and $1 / 320$ respectively using IgM anti-LPS ELISA as a reference test.

Regarding the sensitivity of the 4 brands, it is clear that, Remel brand showed the highest percentages as compared to the other 3 used brands at the 3 cut-off values. However the sensitivity of this brand decreased by increasing the cut-off value, it decreased from $94.02 \%$ at $1 / 80$, to $83.58 \%$ at $1 / 160$ to $56.71 \%$ at $1 / 320$.

Regarding the specificity, Dialab, brand was the most specific brand at the 3 cut-off values. The accuracy of the 4 used brands was almost the same when using a cut-off of 1/160. However, Remel and Biosystems brands

Table 7 Distribution of the results of 91 serum samples using the 4 Widal brands for anti-H antibodies in relation to their corresponding IgM anti-LPS ELISA results using a cut-off $1 / 160$

\begin{tabular}{|c|c|c|c|c|c|c|}
\hline \multirow{3}{*}{$\begin{array}{l}\text { Widal } \\
\text { brand }\end{array}$} & \multirow{3}{*}{$\begin{array}{l}\text { anti-H titer } \geq \\
1 / 160\end{array}$} & \multicolumn{4}{|c|}{ ELISA (91) } & \multirow[t]{3}{*}{ Total } \\
\hline & & \multicolumn{2}{|c|}{ Positive (67) } & \multicolumn{2}{|c|}{ Negative (24) } & \\
\hline & & Number & $\%$ & Number & $\%$ & \\
\hline \multirow[t]{2}{*}{ Remel } & Negative & 11 & 16.41 & 5 & 20.83 & 16 \\
\hline & Positive & 56 & 83.58 & 19 & 79.16 & 75 \\
\hline \multirow[t]{2}{*}{ Biosystems } & Negative & 13 & 19.4 & 7 & 29.16 & 20 \\
\hline & Positive & 54 & 80.59 & 17 & 70.83 & 71 \\
\hline \multirow[t]{2}{*}{ Biotech } & Negative & 18 & 26.86 & 13 & 54.16 & 31 \\
\hline & Positive & 49 & 73.13 & 11 & 45.83 & 60 \\
\hline \multirow[t]{2}{*}{ Dialab } & Negative & 30 & 44.77 & 22 & 91.66 & 52 \\
\hline & Positive & 37 & 55.22 & 2 & 8.33 & 39 \\
\hline
\end{tabular}

Table 8 Distribution of the results of 91 serum samples using the $\mathbf{4}$ Widal brands for anti-H antibodies in relation to their corresponding IgM anti-LPS ELISA results using a cut-off $1 / 320$

\begin{tabular}{|c|c|c|c|c|c|c|}
\hline \multirow{3}{*}{$\begin{array}{l}\text { Widal } \\
\text { brand }\end{array}$} & \multirow{3}{*}{$\begin{array}{c}\text { anti-H titer } \geq \\
1 / 320\end{array}$} & \multicolumn{4}{|c|}{ ELISA (91) } & \multirow[t]{3}{*}{ Total } \\
\hline & & \multicolumn{2}{|c|}{ Positive (67) } & \multicolumn{2}{|c|}{ Negative (24) } & \\
\hline & & Number & $\%$ & Number & $\%$ & \\
\hline \multirow[t]{2}{*}{ Remel } & Negative & 29 & 43.28 & 19 & 79.16 & 48 \\
\hline & Positive & 38 & 56.71 & 5 & 20.83 & 43 \\
\hline \multirow[t]{2}{*}{ Biosystems } & Negative & 35 & 52.23 & 20 & 74.07 & 60 \\
\hline & Positive & 32 & 47.76 & 4 & 25.92 & 31 \\
\hline \multirow[t]{2}{*}{ Biotech } & Negative & 43 & 64.17 & 22 & 91.66 & 67 \\
\hline & Positive & 24 & 35.82 & 2 & 8.33 & 24 \\
\hline \multirow[t]{2}{*}{ Dialab1) } & Negative & 54 & 80.59 & 24 & 100.00 & 78 \\
\hline & Positive & 13 & 19.4 & 0 & 0.00 & 13 \\
\hline
\end{tabular}

were the most accurate brands using the cut-off values of $1 / 80$ (71.42\% for both).

\section{Discussion}

Widal test has been used as an aid in the diagnosis of typhoid fever for more than a century. Since this time its value for the diagnosis of typhoid fever has been debated [11]. The specific purpose of this study was to find an answer to the following debates:

- Are different Widal brands from different manufacturers producing the same results?

Table 9 Sensitivity, specificity and accuracy of the 4 Widal brand for anti-H antibodies of 91 random serum samples of the 150 clinically diagnosed typhoid fever cases using IgM anti-LPS ELISA as a reference test at three cut-off values

\begin{tabular}{cccc}
\hline Widal Brand & sensitivity & specificity & accuracy \\
\hline Using a cut-off $\mathbf{1 / 8 0}$ & & & \\
\hline Remel & $94.02 \%$ & $8.33 \%$ & $71.42 \%$ \\
\hline Biosystems & $91.04 \%$ & $16.66 \%$ & $71.42 \%$ \\
\hline Biotech & $86.56 \%$ & $20.83 \%$ & $69.23 \%$ \\
\hline Dialab & $73.13 \%$ & $45.83 \%$ & $65.93 \%$ \\
\hline Using a cut-off 1/160 & & \\
\hline Remel & $83.58 \%$ & $20.83 \%$ & $67.03 \%$ \\
\hline Biosystems & $80.59 \%$ & $29.16 \%$ & $67.03 \%$ \\
\hline Biotech & $73.13 \%$ & $54.16 \%$ & $68.13 \%$ \\
\hline Dialab & $55.22 \%$ & $91.66 \%$ & $64.83 \%$ \\
\hline Using a cut-off $\mathbf{1 / 3 2 0}$ & & \\
\hline Remel & $56.71 \%$ & $79.16 \%$ & $62.63 \%$ \\
\hline Biosystems & $47.76 \%$ & $74.07 \%$ & $57.14 \%$ \\
\hline Biotech & $35.82 \%$ & $91.66 \%$ & $50.54 \%$ \\
\hline Dialab & $19.40 \%$ & $100.00 \%$ & $40.65 \%$ \\
\hline
\end{tabular}


-Is the Widal test sensitive and specific?

-Which type of antibodies (either $\mathrm{O}$ or $\mathrm{H}$ ) is diagnostic?

-Is the test diagnostic by using a single serum sample or we should have paired sera to show a rising antibodies titer?

In the present study marked discrepancies were obtained when comparing the four used Widal brands at different cut-off values. These discrepancies in results among different brands are supported by Hoffman who stated that the results of single Widal test, tube dilution or slide agglutination test are virtually un-interpretable unless the sensitivity and specificity of the test for the specific laboratory and patient population are known [12]. This is also supported by Olopoenia and King who stated that the value of Widal test depends upon the standardization and maintenance of the antigens to produce consistent results [11].

Regarding the sensitivity and specificity of Widal test the choice of a satisfactory gold standard for diagnosis is crucial. Blood culture-positive patients as the confirmed typhoid fever cases are the usually used gold standard [19]. However, some patients with typhoid fever will be blood culture negative, particularly in areas such as Egypt, where antibiotic pretreatment is common $[14,20]$. Bone marrow culturing would be a better gold standard [21], but this test is not routinely performed.

In the present study both blood and bone marrow cultures were not feasible so we used IgM anti lipopolysaccharide ELISA as our reference test against which we compared the sensitivity and specificity of the used tests. Naediello et al. used IgM anti-LPS ELISA for diagnosis of typhoid where they mentioned that when both sensitivity and specificity were considered, the IgM antiLPS test gave the best discrimination between typhoid patients and controls [22]. Also House et al. mentioned that the anti-LPS IgM ELISA was more sensitive than the Widal TO test in detecting culture confirmed typhoid cases [23].

In this study $\mathrm{O}$ and $\mathrm{H}$ agglutinins were present at a titer of $1 / 80$ in one of the febrile hospital control groups by three of the four used Widal brands (Remel, Biosystems and Biotech) while none showed agglutinins with Dialab brand. It should be mentioned that according to the Egyptian Ministry of Health and Population (MHP) only a positive Widal titer of $1 / 160$ for anti-O and or anti-H antibodies could be considered as a probable typhoid case, concomitant with compatible signs and symptoms of the disease [15]. So if we followed this criterion none of the 25 hospital control groups clinically diagnosed as non typhoid patients will be considered a typhoid positive case.

In this study the sensitivity and specificity of the four used Widal brands at the cut-off value of $1 / 160$ determined by the Egyptian MHP, for both anti-O and anti-H antibodies were compared.

Regarding anti-O antibodies, Remel brand showed the highest sensitivity and accuracy of, $89.50 \%$ and $87.91 \%$ respectively, while Biosystem and Dialab brands showed the highest specificity (95.38\%) each.

Regarding anti-H antibodies, Remel brand also showed the highest sensitivity of $83.58 \%$ but with decreased accuracy of $67.03 \%$, while Dialab brand still showing the highest specificity of $91.66 \%$.

More over, from the results of this study we were able to conclude that Remel brand gave the highest sensitivities and Dialab brand gave the highest specificities for anti- $\mathrm{O}$ and anti-H antibodies at the different 3 cut-off values of $1 / 80,1 / 160$ and $1 / 320$. Indeed, the Dialab was the only brand that did not react non-specifically with the 25 sera of the control febrile cases.

Huckstep have claimed that the level of $\mathrm{H}$ agglutinins is unhelpful in the diagnosis of typhoid, maintaining that the $\mathrm{H}$-agglutinin titer remains elevated for a longer period than the $\mathrm{O}$-agglutinin titer after an episode of typhoid fever and also may rise as a nonspecific response to other infections [16]. However Brodie, Coovadia, Pang and Sommerville have proposed that the $\mathrm{H}$-agglutinin titer is as useful as or more useful than the O-agglutinin titer [9,17-19]. While Parry stated that $\mathrm{H}$ agglutinins were less sensitive but more specific than $\mathrm{O}$ agglutinins and yielded better positive predictive values [20].

In this study, at the diagnostic Egyptian MHP titer of 1/160, $\mathrm{H}$ agglutinins were less sensitive (by all brands except Dialab) and less specific (by all brands) than $\mathrm{O}$ agglutinins and that a raised $\mathrm{O}$ agglutinins was of slightly greater diagnostic value than a raised $\mathrm{H}$ agglutinins.

Many authors stated that the recommended definitive interpretation of the Widal test is a four fold rise in agglutinins in sera taken 7 to 10 days apart $[8,24]$. None of the cases in this study showed three or four fold increase in the antibodies titer using the four Widal brands, and one or two fold increase was the common finding. This finding is supported by Hassanien et al. who stated that four fold rise, in the Widal antibody titer is uncommon and two fold rise is the common finding [25]. Satma et al. stated that four fold antibody rise is rarely demonstrated and two-to three-fold rises are more commonly seen [26]. A four fold increase is not always demonstrable even in blood cultureconfirmed cases. This situation may occur due to many reasons; the early treatment of cases of typhoid fever with antibiotics, lack of antibody response in immunosuppressed patients, the delay in obtaining acute-phase sample in the natural history of the disease and finally the presence of high levels of background antibodies in a region of endemicity $[11,15]$. 


\section{Recommendation}

- An effort must be done to establish a protocol for the standardization of the different commercially available Widal brands to ensure consistent results by different brands.

- Till the achievement of this standardization, we recommend the dual use of two Widal brands to improve the sensitivity and specificity of the test, first by screening sera with a highly sensitive brand and second by tracing false positive cases by testing positive sera in the first testing by a highly specific brand.

- If only one brand is to be used, the cut-off value of this brand must be determined to the community population.

- We recommend the use of acute phase sera using Widal test to diagnose typhoid fever cases and not rely on a 4 fold increase in the antibodies titer using paired sera.

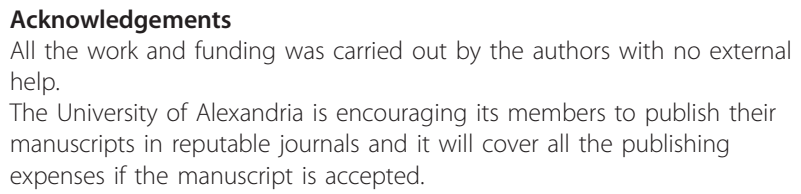

\section{Authors' contributions}

WB participated in the performance of Widal test and ELISA, interpretation of results and drafted the manuscript. LEA participated in the design of the study follow up of the work as a whole and revised the final manuscript. MA participated in the design and coordination. AET carried out the Widal test and ELISA studies and the statistical analysis. All authors read and approved the final manuscript.

\section{Competing interests}

The authors declare that they have no competing interests.

Received: 3 September 2010 Accepted: 8 February 2011

Published: 8 February 2011

\section{References}

1. Abelfadeel M, Crump JA, Mahoney FJ, Nakhla IA: Rapid diagnosis of typhoid fever by enzyme linked immunosorbent assay detection of Salmonella Typhi antigens in urine. Am J Trop Med Hyg 2004, 70(Suppl 3):323-328.

2. Crump JA, Youssef FG, Luby SP, Wasfy MO: Estimating the incidence of typhoid fever and other febrile illnesses in developing countries. J Emerg Infect Dis 2003, 9:539-544.

3. Hardy JA: Characterization of the water and sanitation systems in Fayoum, Egypt. 2010 [http://www.sph.emory.edu/GFE/2003/Hardy.html].

4. Parry CM, Hien MB, Dougan MD, White NJ, Farrar MT: Typhoid fever. N Engl J Med 2002, 347:1770-1782

5. Hunter PR: Fernand Widal. Med Hist 1963, 7(Suppl 1):56-61.

6. Manson-Bahr PEC, Bell DR: Manson's tropical diseases. 19 edition. London: Bailliere- Tindall; 1987, 194-206.

7. Gilman RH, Terminel M, Levine MM, Hernandez-Mendoza P, Hornick R: Comparison of relative efficacy of blood, stool, urine, bone marrow and rose spot cultures for recovery of Salmonella typhi in typhoid fever. Lancet 1975, 1:1211-1215.

8. Sansone P, Saslaw MS, Hennekens CH: High titer Widal reaction. JAMA 1992, 220:1615-1616.
9. Sommerville PC, Lewis M, Koornhof HJ, Alberts M, Raymond R: The Widal test in the diagnosis of typhoid fever in the Transvaal. S Afr Med J 1981, 59(Suppl 24):851-854.

10. Anon: Typhoid and its serology. BMJ 1978, 18:389-390.

11. Olopoenia $L A$, King $A L$ : Widal agglutination test - 100 years later: still plagued by controversy. Postgrad Med J 2000, 76:80-84.

12. Hoffman SL, Flanigan TP, Klancke D: The Widal slide agglutination test, a valuable rapid diagnostic test in typhoid fever patients at the infectious disease hospital in Jakarta. Am J Epidemiol 1986, 123:869-875.

13. Willke A, Ergonul O, Bayar B: Widal test in the diagnosis of typhoid fever in Turkey. Clin Diagn Lab Immunol 2002, 9(Suppl 4):938-941.

14. The Diagnosis, treatment and prevention of typhoid fever. [http://who.int/vaccine_research/documents/en/typhoid_diagnosis.pdf].

15. Clegg A, Passey M, Omena MK, Karigifa K, Sueve N: Re-evaluation of the Widal agglutination test in response to the changing pattern of typhoid fever in the highlands of Papua New Guinea. Acta Tropica 1994, 57(Suppl 4):255-263.

16. Huckstep RL: Typhoid fever and other Salmonella infections. Am J Trop Med Hyg 1963, 12(Suppl 3):451-459.

17. Brodie J: Antibodies and the Aberdeen typhoid outbreak of 1964. I. The Widal reaction. J Hyg 1977, 79:161-180.

18. Coovadia YM, Singh V, Bhana RH, Moodley N: Comparison of passive haemagglutination test with Widal agglutination test for serological diagnosis of typhoid fever in an endemic area. J Clin Pathol 1986, 39:680-683.

19. Pang T, Puthucheary S: Significance of Widal test in the diagnosis of typhoid fever in endemic areas. J Clin Pathol 1983, 36:471-475.

20. Parry CM, Hoa NT, Diep TS: Value of a single Widal test In diagnosis of typhoid fever in Vietnam. J Clin Microbiol 1999, 37:2882-2886.

21. Fletche RH, Halstead SB: Evaluation of diagnostic tests. In Epidemiologic methods for the study of infectious diseases. Edited by: Thomas JC, Weber DJ. New York: Oxford University Press; 2001:198-201.

22. Nardiello S, Pizzella T, Russo M, Galanti B: Serodiagnosis of typhoid fever by enzyme-linked immunosorbent assay determination of antiSalmonella typhi lipopolysaccharide antibodies. J Clin Microbiol 1984, 20:718-721.

23. House D, Wain J, Ho A, Diep S, Chinh N, Bay P, Vinh H, Duc M, Parry C, Dougan G, White N, Hien T, Farrar J: Serology of typhoid fever in an area of endemicity and its relevance to diagnosis. J Clin Microbiol 2001, 39:1002-1007.

24. Gasem MH, Dolmans WM, Isbandrio BB, Wahyono H, Keuter M, Djokomoeljanto R: Culture of Salmonella typhi and Salmonella paratyphi from blood and bone marrow in suspected typhoid fever. Trop Geog Med 1995, 47:164-167.

25. Hassanien F, Mostafa FM, Elbeheiry F, Hammam FM, Allam FA, ElRehawey M: Study of the pattern of Widal test in infants and children; II. Pattern of Widal test in children with enteric fevers. An attempt to define the diagnostic titer for upper Egypt. Gaz Egypt Paediatr Assoc 1975, 23(Suppl 2):173-180.

26. Satma VNB, Malaviya AN, Kumar R: Development of immune response during typhoid fever in man. Clin Exp Immunol 1977, 28:35-39.

doi:10.1186/1476-0711-10-7

Cite this article as: Bakr et al:: The dilemma of widal test - which brand to use? a study of four different widal brands: a cross sectional comparative study. Annals of Clinical Microbiology and Antimicrobials 2011 $10: 7$. 